\title{
Analysis of the Dynamics and Structure of Romanian Public Debt in the Period 2007-2017
}

\author{
Ramona Mariana Călinică \\ ramona.calinica@ugal.ro \\ Dunarea de Jos University of Galati, Romania
}

\begin{abstract}
The public debt of a country presents a major importance when analyzing its financial situation, highlighting its credit, respectively the level of its indebtedness. The purpose of this article is to analyze the structure, causes and ways of financing public debt in general but also its evolution, size and methods of managing it in Romania in particular.
\end{abstract}

Keywords: public debt, budget deficit, financing, creditors

\section{Introduction}

In the situation in wich the main needs of the society can not be financed from the resources attracted in the state budget, ie the financial resources are exceeded, the state through the competent bodies calls for a lending solution, that is to external resources respectively public loans.

It requires a rigorous public debt structure to include details about the currency, maturity and interest. A weak structuring regarding the elements presented ab ove, as well as the existence of a high level of guarantees given by the Government to loans contracted by public institutions or private companies, were factors that contributed to the triggering or propagation of economic crises.[5]

\section{The concept and structure of public debt}

In the conditions in which the revenues of the state budget are exceeded by the expenditures of the budget, to balance the budget, public debt is increased.

In the specialized literature the public debt is defined as the totality of the amounts contracted by the state, the central and local public authorities from individuals or legal persons, from the internal or external market and must be repaid at a certain time.[6]

According to the Romanian legislation, the public debt is represented by the totality of the pecuniary obligations at one time, resulting from loans, in lei and foreign currency, in the short, medium and long term, as well as the state's obligations to its own treasury, for the amounts temporarily advanced in order to cover the deficits of the state budget.[8]

From its structure point of view, public debt takes two forms: local public debt and government debt.

The local public debt is a part of the public debt, which represents all the internal and external financial obligations of the local public administration authorities, at one point, originating from loans contracted directly or guaranteed by them from the financial markets. The governmental public debt is a part of the public debt, which represents the totality of the internal and external financial obligations of the state, at one point, coming from the loans contracted directly or guaranteed by the Government, through the Ministry of Public Finance, on behalf of Romania, from the financial markets.[1]

Regardless of its type, the main mission of public debt management is to provide the sources needed to finance the budget deficit, at the lowest cost and with minimum risks in the 
medium and long term, but also to finance investment projects for the development of the priority sectors of the economy, generating future resources.

External debt represents the amount in foreign currency due, at one point, to a country to other countries or international financial institutions based on loans received by the state and private companies, but with the state guarantee as well as by companies or individuals and to be paid over a period of one year.[2]

Both internal and external public debt is required to grow in a controlled manner so as to fall within certain non-dangerous limits and not create macroeconomic imbalances.

The internal debt represents an unconditional obligation of the state, to repay the loans contracted in lei, to pay the interest and other related costs.[3]

The contracting of public loans from the internal financial market is performed by the Government, within a limit approved by the Parliament, through the Ministry of Finance or other specialized financial institutions.

\section{Management, causes and techniques for extinguishing public debt}

A proper management of the public debt is the satisfaction of the financing needs of the state and its payment obligations at a lower cost in the medium and long term, provided the risks are maintained at a tolerable level. The high costs of public debt can lead, among other things, to the loss of credibility and the capacity of the competent authorities to mobilize internal and external resources.

Ordinary revenues, obtained from the state mainly from taxes and duties, but also from its enterprises and properties, proved to be insufficient in relation to the current needs of money resources and thus appeared the budget deficit, imposing the call of the states to other categories of resources, called generically extraordinary just to show that, unlike the former, their use does not fall within the limits of normal evolution.[7]

The causes of the budget deficits are mainly found in the unfavorable evolution of the real economy, reflected in the evolution of the gross domestic product, as a basis for tax deductions. The repeated and large annual decreases of the GDP have corresponded to the considerable reduction of the budgetary incomes in the real size and at the same time the deepening of the budget deficit.[10]

For any national economy, it is very important to implement and carry out a correct and prudent management of public debt, in order to avoid the inability to pay which can be a consequence of bad and risky loan strategies.

Given that the national economy is in difficulty, without the prospect of reaching a constant, either at a very low level, in order to meet the increasing demands in the budget execution, internal public debt accumulates. Increasing public debt would not be a particularly difficult problem in the context of a forecast, either in the short or medium term. [4]

The most effective way to refund the public debt is to repay it, but practice has shown that paying off public debt can be done by other methods as follows. [5]:

- the reimbursement represents the repayment of the amounts of money to the creditors, at maturity, in instalments or randomly;

- refinancing is a process by which a loan is contracted for the purpose of paying another loan that has reached maturity.

- the inability to pay is when the state declares that it can no longer make payments. In this case some or the entire debt of the state will be canceled.

- monetary depreciation is the way to diminish the real debt of the state, although the nominal debt does not change. This is possible due to inflation eroding borrowed capital.

- repudiation is the method by which the state does not want to pay the debt, even if it has financial resources. 


\section{Analysis of the Romania's public debt evolution}

In Romania, the conditions under which the public, internal and external loans are made, the negotiation and conclusion of agreements and conventions, as well as the use of other legal instruments generating public debt are realized within the institutional framework regulated by Law no. 313 of June 28, 2004 on public debt, published in the Official Monitor, no. 577 of June 29, 2004. [9]

The problems on the international financial markets, which started in 2007 in the USA, were accentuated in 2008, and in the immediate period, the countries of Europe and implicitly Romania also felt the effects of a strong global crisis. If in 2007 the public debt registered a value of 17650.26 million euros, respectively 11.9 of the GDP, in 2008 it increased by $31,76 \%$ to the level of 23257.47 million euros, having a share in the GDP of $12.4 \%$.

The emergence of the economic crisis and the diminution of access to financial markets means that on May 4, 2009 Romania will conclude a new stand-by agreement with the International Monetary Fund, the European Commission, the World Bank and the European Bank for Reconstruction and Development for a financing of about 20 billion euro for two years. Romania has a stand-by agreement with the IMF for two years, for the sum of 12.95 billion euros, money that goes into the BNR reserve, the total package of external financing, from the Fund, the European Union ( 5 billion from the EC), the Bank World (1 billion) and EBRD-EIB-International Finance Corporation (1 billion) totaling 19.95 billion euros.[11]

In the case of our country, the period 2009-2018, was marked by a continuous increase of the public debt from 31,208.15 million euros, respectively $22.1 \%$ of GDP in 2009, to 66390.79 million euros in 2018 , in relative terms, accounting for $34.8 \%$ of GDP. In ceea ce priveste ponderea acesteia in PIB, in perioada 2015-2018 s-a înregistrat un trend ascendent de la 37,80\% din PIB în anul 2015 la 34,80 \% din PIB in anul 2018.

Table 1. Evolution of public debt between 2007-2018

\begin{tabular}{|l|c|c|}
\hline & Total public debt (mil. $\mathbf{)})$ & Share of public debt in GDP (\%) \\
\hline 2007 & 17650.26 & 11.9 \\
\hline 2008 & 23257.47 & 12.4 \\
\hline 2009 & 31208.15 & 22.1 \\
\hline 2010 & 33825.86 & 29.7 \\
\hline 2011 & 40928.35 & 34.0 \\
\hline 2012 & 46998.44 & 36.9 \\
\hline 2013 & 51002.87 & 37.6 \\
\hline 2014 & 55742.77 & 39.2 \\
\hline 2015 & 57218.63 & 37.8 \\
\hline 2016 & 60581.16 & 37.3 \\
\hline 2017 & 63897.17 & 35.1 \\
\hline 2018 & 66390.79 & 34.8 \\
\hline
\end{tabular}

Source: Elaborated by the author based on the data provided by the Ministry of Finance

Analyzing the public debt, from the structural point of view it can be noticed that the evolution of the external public debt had a marked upward trend between 2007-2018, registering an increase from 58316 million lei in 2007, to 219355 million lei in 2018, and that the share of this indicator in GDP was also recorded an increase from $8.3 \%$ to $24.4 \%$. It can be observed that throughout the period analyzed, the highest value was registered by the external public debt contracted for a period of more than 10 years, followed by the one between 5-10 years, and its smallest value is represented by loans granted for a term of up to 5 years. 
International Conference “Risk in Contemporary Economy" ISSN-L 2067-0532 ISSN online 2344-5386 $\mathrm{XX}^{\text {th }}$ Edition, 2019, Galati, Romania,

"Dunarea de Jos" University of Galati, Romania - Faculty of Economics and Business Administration

Table 2. Evolution of external public debt in Romania mil. Lei (RON)

\begin{tabular}{|c|c|c|c|c|c|c|c|c|}
\hline \multirow{2}{*}{$\begin{array}{c}\text { External public } \\
\text { debt }\end{array}$} & 2007 & 2009 & 2011 & 2012 & 2015 & 2016 & 2017 & 2018 \\
\hline & 58316 & 103112 & 135227 & 155283 & 189050 & 200160 & 211116 & 219355 \\
\hline$\%$ PIB & 8,3 & 15,5 & 23,8 & 25,8 & 26,5 & 26,1 & 24,6 & 24,4 \\
\hline $\begin{array}{l}\text { 1. Depending on } \\
\text { the initial duration }\end{array}$ & 58316 & 103112 & 135227 & 155283 & 189050 & 200160 & 211116 & 219355 \\
\hline of the contracted & 4374 & 7733 & 10142 & 11646 & 14179 & 15012 & 15834 & 16452 \\
\hline & 21169 & 37430 & 49087 & 56368 & 68625 & 72658 & 76635 & 79626 \\
\hline $\begin{array}{l}-1-5 \text { years } \\
-5-10 \text { years } \\
\text {-peste } 10 \text { years }\end{array}$ & 32774 & 57949 & 75998 & 87269 & 106246 & 112490 & 118647 & 123278 \\
\hline $\begin{array}{l}\text { 2. Depending on } \\
\text { the creditors: }\end{array}$ & 58316 & 03112 & 135227 & 155283 & 189050 & 200160 & 211116 & 219355 \\
\hline multilateral & 30674 & 54237 & 71129 & 81679 & 99440 & 105284 & 111047 & 115381 \\
\hline credit & 35 & 61 & 81 & 932 & 1134 & 1201 & 1267 & 1316 \\
\hline - bilat & 12946 & 22891 & 30020 & 34473 & 41969 & 44436 & 46868 & 48697 \\
\hline $\begin{array}{l}\text { - private sources } \\
\text { - bond issues }\end{array}$ & 14346 & 25366 & 33266 & 38200 & 46506 & 49239 & 51935 & 53961 \\
\hline
\end{tabular}

Source: Elaborated by the author based on the data provided by the BNR and the Ministry of Finance

According to creditors, the highest value of the public debt is registered to the multilateral creditors, registering a continuous increase from 30674 million lei in 2007 to 115381 million lei in 2018. Bond issues, also have a significant value in the total public debt, recording an upward trend from 14346 million lei in 2007, to 53961 million lei in 2018.

Regarding the internal public debt, it can be noticed that it has registered a daily increase from 2007 and until 2018, from 24,992 million lei, up to 94009 million lei. The analysis of the public debt by types of instruments highlights, between 2007-2019, but especially in 2019, a high value of the internal public debt from other sources (35723 million lei), followed by the state loans (31023 million lei), government bonds (15982 million lei) and treasury certificates (11281 million lei).

Table 3. Evolution of internal public debt in Romania million lei (RON)

\begin{tabular}{|c|c|c|c|c|c|c|c|c|}
\hline & 2007 & 2009 & 2011 & 2012 & 2015 & 2016 & 2017 & 2018 \\
\hline $\begin{array}{c}\text { Internal public } \\
\text { debt }\end{array}$ & 24992 & 44190 & 57954 & 66549 & 81021 & 85782 & 90478 & 94009 \\
\hline$\%$ PIB & 3,6 & 6,6 & 10,2 & 11,1 & 11,3 & 11,2 & 10,5 & 10,4 \\
\hline $\begin{array}{l}\text { from which: } \\
\text { 1. By types of } \\
\text { instruments: } \\
\text { - Treasury } \\
\text { certificates } \\
\text { - government } \\
\text { bonds } \\
\text { - state loans } \\
\text { - other sources }\end{array}$ & $\begin{array}{l}24992 \\
2999 \\
4249 \\
8247 \\
9497\end{array}$ & $\begin{array}{c}44190 \\
5303 \\
7512 \\
14583 \\
16792\end{array}$ & $\begin{array}{c}\mathbf{5 7 9 5 4} \\
6954 \\
\\
9852 \\
19125 \\
22023\end{array}$ & $\begin{array}{r}66549 \\
7986 \\
11313 \\
21961 \\
25289\end{array}$ & $\begin{array}{c}81021 \\
9723 \\
13774 \\
26737 \\
30788\end{array}$ & $\begin{array}{r}85782 \\
10294 \\
14583 \\
28308 \\
32597\end{array}$ & $\begin{array}{r}90478 \\
10857 \\
15381 \\
29858 \\
34382\end{array}$ & $\begin{array}{l}94009 \\
11281 \\
15982 \\
31023 \\
35723\end{array}$ \\
\hline $\begin{array}{l}\text { 2. By types of } \\
\text { holders: } \\
\text { - banking sector } \\
\text { - non-banking }\end{array}$ & $\begin{array}{c}24992 \\
15670 \\
4149 \\
\end{array}$ & $\begin{array}{c}44190 \\
\\
27707 \\
7336 \\
\end{array}$ & $\begin{array}{c}\mathbf{5 7 9 5 4} \\
36337 \\
9620 \\
\end{array}$ & $\begin{array}{l}41726 \\
11047 \\
\end{array}$ & $\begin{array}{l}\mathbf{8 1 0 2 1} \\
50800 \\
13449\end{array}$ & $\begin{array}{l}53785 \\
14240\end{array}$ & $\begin{array}{l}56730 \\
15019\end{array}$ & $\begin{array}{l}58944 \\
15605\end{array}$ \\
\hline
\end{tabular}




\begin{tabular}{|l|c|c|c|c|c|c|c|c|}
\hline $\begin{array}{l}\text { sector } \\
\text { - government } \\
\text { accounts }\end{array}$ & 5173 & 9147 & 11996 & 13776 & 16771 & 17757 & 18729 & 19460 \\
\hline $\begin{array}{l}\text { 3. Depending on } \\
\text { the maturity: } \\
\text {-short term } \\
\text {-medium and } \\
\text { long term }\end{array}$ & $\mathbf{2 4 9 9 2}$ & $\mathbf{4 4 1 9 0}$ & $\mathbf{5 7 9 5 4}$ & $\mathbf{6 6 5 4 9}$ & $\mathbf{8 1 0 2 1}$ & $\mathbf{8 5 7 8 2}$ & $\mathbf{9 0 4 7 8}$ & $\mathbf{9 4 0 0 9}$ \\
\hline
\end{tabular}

Source: Elaborated by the author based on the data provided by the BNR and the Ministry of Finance

Depending on the holders, it can be observed that the highest value of the internal public debt is to the banking sector and has increased during the analyzed period from 15670 million lei in 2007 to 58,944 million lei in 2018. The second important category of holders is represented by the government accounts, which also registered an upward trend of 19460 million lei.

Regarding the maturity it can be observed that the domestic public debt in the short term holds an important amount of the total internal public debt, over the $50 \%$ percentage during the whole period analyzed, reaching in 2019 the value of 57,534 million lei.

\section{Conclusions}

If the state budget revenues are exceeded by the budget expenditures, in order to balance the budget the public debt is increased, the real challenge consisting in a good management of it keeping an acceptable level in the medium and long term of the risk and ensuring resources for the payment of debt service at the lowest possible cost.

Also public debt must grow in a controlled manner, not exceeding the legal limit and avoiding the explosive growth of public debt.

Currently, public debt is a common phenomenon in the economies of different countries, but its share differs from country to country. The problems on the international financial markets, triggered since 2007 in the USA, were accentuated in 2008, and in the near future, the countries of Europe and implicitly Romania, have fully felt the effects of a strong global crisis. Thus, throughout the period analyzed the level of public debt has continuously increased in Romania, and from the structural point of view the external public debt had the highest share.

In general, the loans that make up the public debt are contracted to finance the budget deficit, strengthen the foreign exchange reserve, make investments or maintain the balance of payments, but the level of public debt must increase in a controlled way, not exceeding the legal limit and avoiding it its explosive growths.

\section{References}

1. Călin, M., Datoria publică, Editura Didactică și Pedagogică, București 2000, p.41

2. Ceauşu, I. ,Dictionar enciclopedic managerial, Vol. I, Editura Academică de Management, București, 2000, p. 264.

3. Clipici, E., Rădulescu M.,Integrare Europeană in contextul globalizării economice" Editura Agir, București, 2003, p.226

4. Gherghina, R., Cretan G., Finante, Editura Universitara, Bucuresti,2012

5. Mosteanu, T., Câmpeanu E, Cataramă D, Mircescu E., Gestiunea datoriei publice, Editura Universitară, 2008, p. 7-10

6. Negrea, A., Finante publice, Editura Ex Ponto, Constanta, 2009, p. 213 
International Conference “Risk in Contemporary Economy” ISSN-L 2067-0532 ISSN online 2344-5386

$X^{\text {th }}$ Edition, 2019, Galati, Romania,

"Dunarea de Jos" University of Galati, Romania - Faculty of Economics and Business Administration

7. Ștefura, G., România şi problemele integrării europene, Editura Universitară Alexandru Ioan Cuza, Iaşi, 2005

8. Legea privind datoria publică, publicată în Monitorul Oficial nr.577 din 29 iunie 2004

9. Legea 313/2004, publicată in Monitorul Oficial nr. 577/2004, a fost adoptată de Parlamentul României, cu respectarea prevederilor art. 75 și ale art. 76 alin.(1) din Constitutia României.

10. bttps:// wnw.financialmarket.ro/terms/deficit-bugetar/, accesat la 22.03.19

11.bttp:// siteresources.worldbank.org/ROMANIAINROMANLANEXTN/Resources/Oct_31_Justin Lin_KDI_remarks_RO.pdf, accesat la 06.04.2019 